\title{
Prudential Principles in Regulation of Land Registration in Indonesia
}

\author{
Ilgiz Bross; Hamzeh Khan
}

The Islamic Economics Program, University in Depok, Indonesia

Ross_gios@ui.ac.id

\begin{abstract}
Land registration is the first step for landowners to have legal ownership certificates and be recognized by the state in the form of land certificates, the raw errors in land registration result in multiple interpretations of legal certainty regarding land data that will harm landowners, so the principle of prudence in registration land is very important to be applied so that in the registration process there is no mistake and legal certainty is guaranteed from the certificate issued. This study aims to find out and analyze the extent to which the principle of prudence is regulated in land registration regulations so that the implementation of land registration is carried out correctly and appropriately. The type of research used in this research is normative legal research, namely research based on legal materials whose focus is on reading and studying the materials of primary law and secondary law. The results of this study indicate that the principle of prudence has been stipulated in the land registration law by observing the principle of prudence indicators contained in the article per an article in the land registration law such as the Law of the Republic of Indonesia Number 5 of 1960 concerning Regulations Basic Agrarian Principles, Republic of Indonesia Government Regulation Number 24 of 1997 concerning Land Registration, Agrarian Minister Regulation Number 3 of 1997 concerning Provisions for Implementing Government Regulation number 24 of 1997 concerning land registration, and Regulation of the Head of National Land Agency of the Republic of Indonesia number 1 of 2010 about Land Service and Regulatory Standards.
\end{abstract}

Keyword: Accuracy, Accountability; Legal Certainty; Regulation of Land Registration

\section{Introduction}

Land plays a very strategic role in various sectors of human life, very strategic aspects are economic aspects, political aspects and legal aspects. (Idham, 2004). These three aspects are interrelated thoughts as an integrated unit in taking the process of land law policy carried out by the government and also to guarantee legal certainty. To arrive at certainty, the law must contain openness, so that anyone can understand the meaning of a legal provision. One law with another law must not be contradictory, because if so, it becomes a source of doubt. If there is a contradiction, such opposition must be terminated as soon as possible through the legal system itself. Legal certainty is one of the most frequently questioned things. Legal certainty can be interpreted as enforcing the law explicitly in society (Wantu, 2011). 
The urgency related to legal certainty over ownership rights over the land The government responded by issuing Law Number 5 of 1960 concerning Basic Agrarian Principles to regulate all matters relating to earth, water and space. In Article 19 the Basic Agrarian Law mandates that throughout the territory of the Republic of Indonesia land registration that is rechad cadastre be held so as to guarantee legal certainty. Land registration activities which at the time give birth to proof of ownership of land rights in the form of certificates (Hatta Isnaini Wahyu Utomo, 2017).

The implementation of land registration in accordance with the provisions of Law Number 5 of 1960 concerning Basic Agrarian Principles in Article 19 Jo Government Regulation Number 10 of 1961 concerning Land Registration which has been amended by Government Regulation Number 24 of 1997 is the responsibility of the Government to register land throughout the territory of Indonesia. Land registration has the purpose:

1. To provide legal certainty and legal protection to the holders of rights to a plot of land, apartment units and other registered rights so that they can easily prove themselves as holders of the relevant rights.

2. To provide information to interested parties including the Government so that it can easily obtain the data needed in conducting legal actions regarding plots of land and units of flats that have been registered.

3. For the orderly implementation of land administration.

By considering the above provisions, the purpose of registration of land is not only for legal certainty but also for legal protection. This legal certainty and legal protection is very closely related to the position of the certificate as proof of land rights which is an evidence that explains the subject and object of rights to the land and can be used to defend claims from third parties. Regarding the strength of the proof of certificate explicitly Government Regulation Number 24 of 1997 in Article 32 states that the certificate is a strong proof of physical data and juridical data contained in it, as long as the physical data and juridical data are in accordance with the data in the measurement and books the land of rights concerned.

In carrying out the objectives of the Basic Agrarian Law to register land for the achievement of legal certainty over land ownership rights to date it has not been fully implemented. This is because the community does not fully understand the importance of proof of ownership of land rights in the form of certificates, most of the communities mainly in rural areas still consider the proof of tax collection, commonly referred to as Letter C, Letter D, Girik and others, as proof of ownership rights land, the community generally does not understand that in the cadaster fiscal registration concept the main purpose is not to guarantee legal certainty, but to determine who is obliged to pay the land tax.

In this condition, in the end, the community becomes vulnerable if there is a dispute over the transfer of land because the proof of ownership is not the strongest evidence, in general the function of a land certificate is a strong evidence that the rights holder or person whose name is listed in the land certificate the person entitled to the land concerned.

The lack of public knowledge about the proof of ownership of the land forces the government to apply the principle of prudence in land registration in order to achieve legal certainty and legal protection. This legal certainty and legal protection is very closely related to the position of the certificate as proof of land rights which is an evidence that explains the subject and object of rights to the land and can be used to defend claims from third parties. 
Regarding the power of certifying the certificate explicitly Government Regulation No. 24 of 1997 in Article 32 states that the certificate as a strong proof of physical data and juridical data contained therein, as long as the physical data and juridical data are in accordance with existing data in measuring tides and books the land of rights concerned. This statement is a consequence of the land registration system adopted in Indonesia which uses a negative system, which means that the state does not guarantee the accuracy of the data contained in the certificate. But even so according to what is stated in the explanation of Government Regulation Number 24 of 1997, the negative publicity system adopted is not purely because in the provisions of Article 19 paragraph (2) letter c of the Basic Agrarian Law, that the proof of rights issued applies as a tool strong evidence, in addition to the procedures for collecting, processing, storing and presenting physical data and juridical data to present correct data. The consequence that must be done to produce the correct data is the application of the principle of prudence by the party who has the authorization as the executor of land registration, so that there are no errors, errors or falsification of data which results in incorrect data in every land registration process. The party authorized by the state to carry out this land registration is the National Land Agency, whose implementation is delegated to the Regency / City Land Office.

The principle of prudence has finally become an interesting discussion to be discussed considering the various types of land conflicts that occurred in land registration and resulted in legal uncertainty in the ownership of land certificates. Regulations regarding the principle of prudence contained in the laws and regulations need to be studied more deeply so that government services on land registration are on target and not misused by irresponsible parties.

\section{Research Methods}

The type of research used in this research is normative legal research, namely research based on legal materials whose focus is on reading and studying the materials of primary law and secondary law. The research in writing this law is prescriptive is to provide arguments from the results of research that has been done because it tries to find legal rules, legal principles, as well as legal doctrines which are then analyzed by referring to describing applicable laws and regulations relating to legal theory and positive practice of law regarding problems in this writing (Marzuki, 2010).

\section{Results and Discussion}

1. Understanding and indicators of the principle of prudence in land registration

a. Understanding the principle of prudence

The definition of principle is a fundamental statement or general truth that can be used by someone as a guideline in acting. The definition of principle is often equated with the asas, which is basically the notion of asas itself is something that is the foundation of thinking in opinion. The existence of the principle here is clearly influenced by the existence of a asas that has existed before as the subject matter, in the sense that the asas becomes the basis of thinking which then forms the principles to act in accordance with the existence of the asas that has prevailed before. This makes the writer use the principle word in the discussion of the principle of prudence in land registration, because caution itself means an action taken to prevent future uncertain losses from a decision or action. 
The term "prudence" in the dictionary of Indonesian means to pay close attention. Understanding "such caution contains the mandate that in the context of State management, every State apparatus in registering land must carry out their duties and functions in a responsible and serious manner for the benefit of the State and society based on the applicable laws and regulations. So that it can be implied that the principle of prudence can be interpreted as a basis for truth which is the basis of thinking and acting with great care so that nothing will happen in the future (Usman, 2003).

\section{b. Indicator of the principle of prudence}

The principle of prudence is an important reference to be applied by the government to create clean and authoritative governance (good governance and clean government) even the application of the principle of prudence is one of the strategic steps to prevent misuse of land rights by those who do not to be responsible.

In referring to the Good General Principles of Government in Law Number 28 of 1999 concerning the Implementation of a Clean and Free of Corruption, Collusion and Nepotism Countries the application of the principle of prudence in land registration has indicators that reflect a caution, that is:

\section{1) Principle of Legal Certainty}

- Government decisions based on laws and regulations that are clear, strong and do not violate the law, the provisions in the decision are arranged in clear words or not multiple interpretations / runaway

- Decisions contain certainty and will not be revoked, may not be retroactive

- Decisions must respect the rights that have been obtained based on a government decision

2) Principle of Accountability

- The principle that determines that every activity and the final outcome of state administration activities must be accountable to the public or the people as the highest holder of state sovereignty in accordance with the prevailing laws and regulations.

3) Principle of Openness

- Principles that open themselves to the right of the community to obtain information that is true, honest and non-discriminatory about the administration of the state while taking into account the protection of personal rights, groups and state secrets.

- Making decisions must pay attention and open up to the right of the community to express their aspirations, obtain correct, honest and impartial information.

- Decisions made must be based on rules and procedures that are open and clear in every policy making

- Regulations and delegations of related parties that are clearly in accordance with the level of authority

4) Principle of Accuracy

- Decisions and actions produced must be based on complete documents

- Decisions must comprehensively consider all aspects of the decision material so as not to cause harm to citizens

- Decisions are based on hearing the parties concerned, a decision must be prepared and taken carefully (full of caution), taken correctly and in accordance with the target / object, must pay attention and listen to the parties concerned before they are confronted on an adverse decision. 
By understanding and applying the indicators of the principle of prudence mentioned above, it is expected that land registration in Indonesia can be carried out correctly so that people who have a direct interest in land registration are not harmed by policies issued by government agencies, especially the National Land Agency as certificate issuer in Indonesia.

2. Legislation concerning land registration that contains an indicator of the principle of prudence.

Broadly speaking, the principle of prudence has been applied in several regulations regarding land registration, such as:

a. Law of the Republic of Indonesia Number 5 of 1960 concerning Basic Agrarian Principles

In the basic agrarian basic arrangement, the principle of prudence contained is contained in article 19 paragraph (1) where this article reads:

"to ensure legal certainty by the Government of the Republic of Indonesia, registration of land is carried out throughout the territory of the Republic of Indonesia according to the provisions regulated by Government Regulations"

In this article, it can be interpreted that the indicator of the principle of prudence is legal certainty because in the article the government held land registration throughout the territory of Indonesia so that ownership of land rights did not overlap, clear procurement was given to landowners who had been recognized by the state with land registration.

b. Republic of Indonesia Government Regulation number 24 of 1997 concerning Land Registration

Arrangements regarding land registration are regulated in Government Regulation No. 24 of 1997 concerning Land Registration, where in the articles there are indicators of the principle of prudence, one of which is in article 3 concerning the purpose of land registration, letter (a) reads:

"to provide legal certainty and legal protection to holders of rights to a plot of land, apartment units and other registered rights so that they can easily prove themselves as holders of the relevant rights"

It is clear that the principle of prudence indicator in this article is in the form of certainty for the landowner, then in letter $(\mathrm{b})$ it reads:

"to provide information to interested parties including the government so that it can easily obtain the data needed in conducting legal actions regarding plots of land and units of flats that have been registered"

This letter contains an indicator of the principle of prudence in the form of the principle of openness because in the registration of land information can be obtained from interested parties.

After the article describing the purpose of the land registration, there are also indicators of the principle of prudence in article 6 paragraph 2 which reads:

"in carrying out land registration, the Head of the Land Office is assisted by PPAT and other Officials who are confirmed to carry out certain activities according to this Government Regulation and the relevant laws and regulations" 
Issuance of certificates assisted by Land Deed Officials proves the existence of a principle of prudence in land registration, because the Land Deed Making Officer is the state official who is tasked with issuing authentic deeds regarding land, meaning all land registration must be legalized by the Land Deed Official and obtain legal certainty through authentic certificates that are banned.

In addition to the above article, there is also an article containing the principle of prudence, which is contained in article 12, in this article it is regulated on activities in land registration, where the principle of prudence is based on careful principles, because in an activity already regulate in this article is the stage that must be passed in a land registration, accuracy becomes the basis of this registration activity because if something goes wrong because of lack of accuracy it will result in data errors on the ground and confusion that results in legal uncertainty

c. Regulation of the Minister of Agrarian Affairs number 3 of 1997 concerning Provisions for the Implementation of Government Regulation number 24 of 1997 concerning Land Registration

Related to the implementation of the principle of prudence indicator in the Regulation of the Minister of Agrarian number 3 of 1997 concerning Provisions for Implementation of Government Regulation number 24 of 1997 concerning Land Registration can be found in articles 50, 51, 52, 53, 54 concerning the Arrangement, Tasks and Authority of the Adjudication Committee and Task Force, in some of these articles, it is explained about the duties and authorities of land registration officers who can be interpreted that in carrying out their duties these officers must apply the principle of prudence carefully and carefully so as not to make mistakes in carrying out their duties because in carrying out his duties the land registration officer carries out negligence, there will be a loss for the land registrants. The principle of prudence is also contained in article 56 concerning counseling, in this article it contains the principle of prudence which is classified as the principle of openness, because in this article it is explained about counseling about open land registration so that registrants know clearly about land objects which will be listed, then in article 60 it is explained about written evidence which can be interpreted that this evidence is legal certainty in ownership of land rights, so that ownership of written evidence can be a form of principle of legal certainty which is an indicator in principle caution in land registration.

d. Regulation of the Head of the National Land Agency of the Republic of Indonesia Number 1 of 2010 concerning Service Standards and Land Arrangement concerning Land Registration.

Regarding the principle of prudence indicator in this regulation which explains the service standards in the National Land Agency, it is contained in article 6 paragraph 3 which reads.

"if the requirements referred to in paragraph (2) are incomplete, the Land Office, Regional Office of the National Land Agency rejects the application file"

In this article, it is explained that the people who wish to register their land must attach a number of conditions to ensure ownership and reality of the land they control, so that there will be no mistakes in the future regarding the land objects listed. The act of rejecting the submission of registration with incomplete conditions is one step in applying the principle of prudence.

\section{Conclusion}

The principle of prudence in land registration is a basis for careful and open thinking in land registration procedures in order to ensure legal certainty on registered land rights, considering all possibilities to avoid problems in the future after the issuance of land rights. 
The indicators of the principle of prudence set out in the land registration regulations should be taken seriously by the government so as not to harm the community.

\section{Acknowledgement}

Regulations regarding the principle of prudence must be strictly regulated in a special rule so that it becomes a guideline in special public services in land registration services. The need for counseling for the wider community, especially in the regions about the importance of land registration so that the land owned has strong legal force so that there is no misuse of land registration by irresponsible people.

\section{Reference}

Aminanto, Kif, Supremasi Hukum, Jember Katamedia, Jember, 2017.

Bakri, M., Pengantar Hukum Indonesia, Pembidangan dan Asas-Asas Hukum Jilid II, UB Press, Malang, 2015.

Curzon, L.B., Jurisprudence, M\&E Handbook, 1979.

Fence M. Wantu, 2011, Idee Des Recht (Kepastian Hukum, Keadilan, dan Kemanfaatan), Jogyakarta, Pustaka Pelajar. Page 89.

Hatta Isnaini Wahyu Utomo, 2017, Prinsip kehati-hatian Pejabat Pembuat Akta Tanah dalam Peralihan Tanah yang belum bersertifikat, Yogyakarta, Jurnal Hukum Ius Quia Iustum No.3, UII, vol.24, Page 48.

Hatta Isnaini Wahyu Utomo, 2017, Prinsip kehati-hatian Pejabat Pembuat Akta Tanah dalam Peralihan Tanah yang belum bersertifikat, Yogyakarta, Jurnal Hukum Ius Quia Iustum No.3, UII, vol.24, Page 469.

Idham, 2004, Konsolidasi Tanah Perkotaan Dalam Perspektif Otonomi Daerah, Bandung, Alumni, Page 1.

Peter Mahmud Marzuki, 2010, Penelitian Hukum, Jakarta, Kencana Prenada Media Group, Page 22.

Rachmadi Usman, 2003, Aspek-Aspek Hukum Perbankan Indonesia, Jakarta, Gramedia Pustaka Utama, Page 11.

\section{Copyrights}

Copyright for this article is retained by the author(s), with first publication rights granted to the journal.

This is an open-access article distributed under the terms and conditions of the Creative Commons Attribution license (http://creativecommons.org/licenses/by/4.0/). 